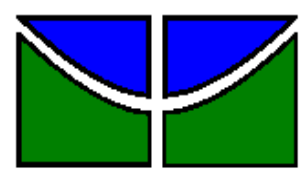

Universidade de Brasília - UnB

Faculdade de Economia, Administração, Contabilidade e Ciência da Informação e Documentação - FACE Programa de Pós-Graduação em Administração - PPGA Curso de Especialização em Gestão de Programas e Projetos Educacionais

DAÊR JOSÉ VIEIRA DA MOTTA

\title{
FUNDEB NO ESPÍRITO SANTO SOB OS EFEITOS DO FUNDAP
}

BRASÍLIA-DF 
DAÊR JOSÉ VIEIRA DA MOTTA

\section{FUNDEB NO ESPÍRITO SANTO SOB OS EFEITOS DO FUNDAP}

Monografia apresentada como exigência para obtenção do título Pós-Graduação, no curso de Especialização em Gestão de Programas e Projetos Educacionais

Orientador:

Mestre Vander Oliveira Borges 


\section{Resumo}

O presente trabalho objetiva uma reflexão acerca dos impactos decorrentes da redução de recursos alocados no Fundo de Manutenção e Desenvolvimento da Educação Básica e de Valorização dos Profissionais da Educação - FUNDEB, criado em substituição ao Fundo de Valorização do Ensino Fundamental - FUNDEF, especificamente no exercício de 2007, decorrente da arrecadação a menor do Estado do Espírito Santo, onde, por força de legislação estadual, foi instituído o Fundo para Desenvolvimento das Atividades Portuárias - FUNDAP, cujos recursos são destinados a promover o incremento das exportações e importações pelo porto de Vitória. Para o alcance de seus objetivos, o FUNDAP conta com recursos financeiros de diversas fontes, entre elas figura a retenção de $8 \%$ do saldo do Imposto sobre a Circulação de Mercadorias e Serviços - ICMS recolhido das empresas participantes do Fundo. Verificou-se como a retenção de recursos, que ocorre antes que seja apurado o valor a ser recolhido ao FUNDEB, impactou negativamente o FUNDEB, e qual danoso para o alcance dos objetivos do FUNDEB é esta redução de recursos. Utilizou-se como método de pesquisa, a pesquisa documental. Finalizando o trabalho, verificou-se que o assunto não será esgotado, pois o verdadeiro impacto da redução de recursos alocados no FUNDEB, somente será apurado em sua plenitude com o acompanhamento sistemático das ações desenvolvidas, o desempenho e progressão curricular dos alunos e a defasagem salarial dos professores.

Palavras-chave: Educação. Ensino Fundamental. Financiamento. Fundef. Fundeb. Fundap. Espírito Santo. 


\begin{abstract}
This work aims to reflect on the impacts arising from the reduction in resources allocated in the Fund for Maintenance and Development of Basic Education and Professional Development of Education - FUNDEB, created to replace the Fund for Development of Basic Education - FUNDEF, specifically in the exercise 2007, due to the lower revenues of the State of Espirito Santo, where, under state law, was established the Fund for Development of Port Activities - FUNDAP, whose resources are to promote the growth of exports and imports through the port of Victoria . To reach their goals, the FUNDAP account with funds from various sources, including the retention figure of $8 \%$ of the balance of Tax on Circulation of Goods and Services - ICMS collected from companies participating in the Fund. It was found as the withholding of resources, which occurs before it is determined the amount to be collected to FUNDEB, the FUNDEB negatively impacted, and what harmful to achieve the objectives of FUNDEB is the reduction of resources. It was used as a method of research, documentary research. Terminating the work, it appeared that the matter will not be exhausted because the real impact of the reduction of resources allocated in FUNDEB, will only be found in its fullness with the monitoring of actions undertaken, the performance and progress of students and curriculum wage gap of teachers.
\end{abstract}

Keywords: Education. Primary School. Financing. FUNDEF. FUNDEB. Fundap. Holy Spirit. 


\title{
Lista de Abreviaturas e Siglas
}

\author{
BANDES Banco de Desenvolvimento do Espírito Santo S/A \\ CDB Certificado de Depósito Bancário \\ E C Emenda Constitucional \\ FNDE $\quad$ Fundo Nacional de Desenvolvimento da Educação \\ FPE $\quad$ Fundo de Participação dos Estados \\ FPM Fundo de Participação dos Municípios \\ FUNDEB $\quad$ Fundo de Manutenção e Desenvolvimento da Educação Básica \\ FUNDEF Fundo de Manutenção e Desenvolvimento do Ensino Fundamental e de \\ Valorização do Magistério
}

FUNDESCOLA Fundo de Fortalecimento da Escola

ICMS Imposto sobre Circulação de Mercadorias e Serviços

IPIexp. Imposto sobre Produtos Industrializados, proporcional às exportações

ITR Imposto sobre a Propriedade Territorial Rural

IPVA Imposto sobre a Propriedade de Veículos Automotores

ITCMD Imposto sobre Transmissão Causa Mortis e doações de quaisquer bens e direitos

LDB Lei de Diretrizes e Bases da Educação

MP Medida Provisória

SINAPI Sistema Nacional de Pesquisa de Custos e Índice da Construção Civil 


\section{Lista de Tabelas e Gráficos}

Tabela 1 Percentuais de recursos de cada fonte alocados no FUNDEB ........ 17

Gráfico 1 Percentual dos Impostos alocados no FUNDEB pelo Estado do Espírito Santo no exercício de 2007 .............................................. 18

Tabela 2 Recursos oriundos do ICMS não alocados no FUNDEF ................ 24

Tabela 3 Impacto negativo acarretado pelo Estado do Espírito Santo no

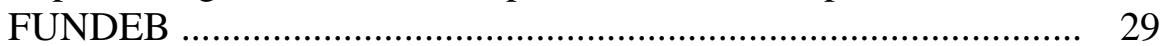

Tabela $4 \quad$ Distribuição por destinação da Diferença apurada.......................... 32

Tabela $5 \quad$ Contratação de Docentes .............................................................. 33

Tabela $6 \quad$ Pagamento de salário extra ......................................................... 33

Tabela 7 Simulação: Retorno de financiamento $\mathrm{X}$ resultado da aplicação financeira ................................................................................ 42 


\section{Sumário}

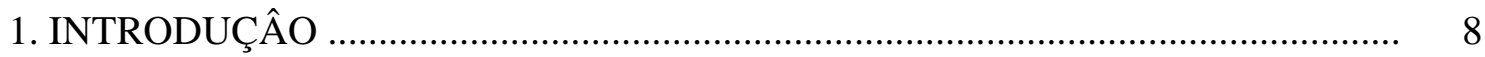

2. CONHECENDO O FNDE, FUNDEB e FUNDAP .................................................. 11

2.1 O Fundo Nacional de Desenvolvimento da Educação - FNDE ................................. 11

2.2 O Fundo de Manutenção e Desenvolvimento da Educação Básica e de Valorização dos Profissionais da Educação - FUNDEB......................................... 11

2.3 O Fundo para Desenvolvimento das Atividades Portuárias - FUNDAP .................. 20

3. CONFLITOS DE LEGISLAÇÃO …............................................................... 25

4. IMPACTO FINANCEIRO NO FUNDEB .......................................................... 29

5 CONCLUSÃO

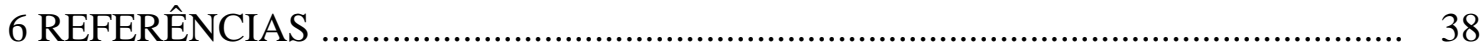




\section{INTRODUÇÃO}

Até o final do ano de 2006, vigorou o Fundo de Manutenção e Desenvolvimento do Ensino Fundamental e de Valorização do Magistério (FUNDEF), que era um Fundo de natureza contábil, instituído pela Emenda Constitucional n. ${ }^{\circ}$ 14, de 12 de setembro de 1996, e regulamentado pela Lei $n .^{\circ} 9.424^{1}$, de 24 de dezembro do mesmo ano, e pelo Decreto $\mathrm{n}^{\mathrm{o}}$ $2.264^{2}$, de 27 de junho de 1997. O FUNDEF foi implantado, nacionalmente, em $1^{\circ}$ de janeiro de 1998, quando então passou a vigorar esse novo mecanismo de redistribuição de recursos destinados ao ensino fundamental

Os recursos do FUNDEF destinavam-se ao financiamento de ações de manutenção e desenvolvimento do ensino fundamental público, independentemente da modalidade em que o ensino era oferecido (regular, especial ou de jovens e adultos), da sua duração (de oito ou de nove anos), da idade dos alunos (crianças, jovens ou adultos), do turno de atendimento (matutino, vespertino ou noturno) e da localização da escola (na zona urbana ou na zona rural).

Financeiramente, o FUNDEF era composto, basicamente, por recursos dos próprios Estados, Distrito Federal e Municípios, sendo constituído de parcela de 15\% do:

o Fundo de Participação dos Estados - FPE

o Fundo de Participação dos Municípios - FPM

o Imposto sobre Circulação de Mercadorias e Serviços - ICMS (incluindo os recursos relativos à desoneração de exportações, de que trata a Lei Complementar nº 87/96)

o Imposto sobre Produtos Industrializados, proporcional às exportações - IPIexp.

Além desses recursos, entrava na composição do FUNDEF, a título de complementação, parcela de recursos federais, com o objetivo de assegurar um valor mínimo por aluno/ano ${ }^{3}$ aos Governos Estadual e Municipais no âmbito do Estado onde este valor per capita não era alcançado.

\footnotetext{
${ }^{1}$ publicada no Diário Oficial da União de 26 de dezembro de 1996.

${ }^{2}$ Publicado no Diário Oficial da União de 28 de junho de 1997 (Edição Extra)

${ }^{3}$ a fixação do valor mínimo por aluno esta contida no $\S 1^{\circ}$, art. $4^{\circ}$ da Lei $n^{\circ} 11.494$ de 20 jun.2007.
} 
Em substituição ao FUNDEF, a partir de $1^{0}$ de janeiro de 2007 teve inicio a implantação do Fundo de Manutenção e Desenvolvimento da Educação Básica e de Valorização dos Profissionais da Educação - FUNDEB, instituído pela Emenda Constitucional $n^{\circ}$ 53, de 19 de dezembro de 2000, regulamentado pela Medida Provisória ${ }^{\circ}$ 339, de 28 de dezembro de 2006, posteriormente convertida na Lei $n^{\circ} 11.494^{4}$, de 20 de junho de 2007.

Ainda em implantação, e com previsão de conclusão em 2009, abrangerá todo o universo de alunos da educação básica pública presencial.

Assim como foi o FUNDEF, o FUNDEB é um fundo especial de natureza contábil de âmbito estadual (um fundo por estado e Distrito Federal, num total de vinte e sete fundos), formado por parcela financeira federal e por recursos provenientes dos impostos e transferências dos estados, Distrito Federal e municípios, vinculados à educação por força do disposto no art. 212 da Constituição Federal.

O art. $3^{\circ}$ da Lei $n^{\circ} 11.494$ de 2007, enumera as fontes de recursos do FUNDEB, entre elas destacamos a que consta no subitem II, qual seja:

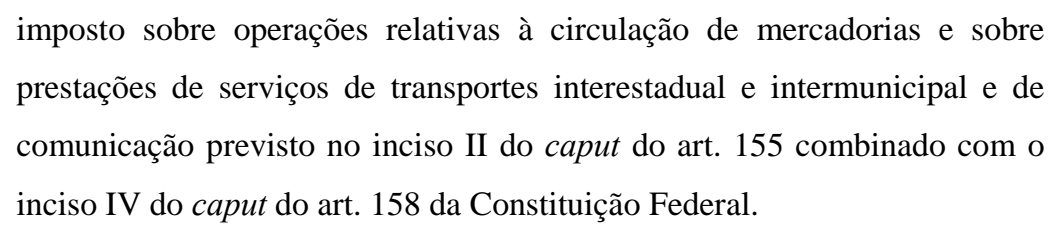

Quando da existência do FUNDEF, parcela de 15\% dos recursos arrecadados com esse imposto compunha o fundo. Com o advento do FUNDEB, as parcelas aumentaram progressivamente: 16,66\% em 2007; 18,33\% em 2008 devendo atingir o patamar de 20\% em 2009, com previsão de manutenção deste índice para o período de 2010 a $2020^{5}$.

Ocorre que no Estado do Espírito Santo, foi instituído pela Lei $\mathrm{n}^{\circ} 2.508^{6}$, de 22/05/1970 (alterada posteriormente), o Fundo para Desenvolvimento das Atividades Portuárias - FUNDAP, cujos recursos são destinados a promover o incremento das exportações e importações pelo porto de Vitória.

\footnotetext{
${ }^{4}$ Publicada no Diário Oficial da União de 21 jun.2007.

${ }^{5}$ os índices estão definidos nos incisos I e II do $§ 1^{\circ}$, art. 31 da Lei n ${ }^{\circ} 11.494$ de 2007.

${ }^{6}$ publicada no Diário Oficial do Estado do Espírito Santo de 22 mai. 1970.
} 
Para o alcance de seus objetivos, o FUNDAP conta com recursos financeiros de diversas fontes, entre elas figura a retenção de 8\% do saldo do Imposto sobre a Circulação de Mercadorias e Serviços - ICMS recolhido das empresas participantes do Fundo.

A retenção ocorre antes que seja apurado o valor a ser recolhido ao Fundo de Manutenção e Desenvolvimento da Educação Básica e de Valorização dos Profissionais da Educação - FUNDEB, o que implica na alteração da base de calculo para determinação dos valores a serem alocados no FUNDEB, e por conseqüência, a diminuição dos recursos disponibilizados.

Assim, o presente trabalho busca trazer uma reflexão acerca do impacto da redução de recursos alocados pelo Estado do Espírito Santo, no pleno cumprimento dos objetivos do FUNDEB.

Por sua natureza e destinação, neste trabalho será analisado somente o exercício de 2007, não esgotando assim, a análise do assunto, pois o verdadeiro impacto da redução de recursos alocados no FUNDEB, somente será apurado em sua plenitude com o acompanhamento sistemático das ações desenvolvidas, o desempenho e progressão curricular dos alunos e a evolução salarial dos professores.

O estudo constitui-se de uma parte introdutória, onde é contextualizado o problema e é explicitado o objetivo de sua realização. Consta, a seguir, a fundamentação teórica, contendo uma apresentação do FNDE, FUNDAB, FUNDEF e FUNDAP. A terceira parte trata dos conflitos de legislação que envolve a sistemática adotada pelo Estado do Espírito Santo, logo em seguida são feitas algumas projeções demonstrado o impacto da redução de recursos no FUNDEB e apresentada a conclusão do trabalho.

Ao demonstrar o qual danoso é a pratica adotada pelo Estado do Espírito Santo em relação ao FUNDEB no exercício de 2007, espera-se proporcionar maior visibilidade ao tema; contribuir para sua discussão e despertar o interesse para ampliação de igual apuração em outros exercícios. 


\section{Conhecendo o FNDE, FUNDEB e o FUNDAP}

\subsection{O Fundo Nacional de Desenvolvimento da Educação - FNDE}

O Fundo Nacional de Desenvolvimento da Educação - FNDE, Autarquia Federal, criada pela Lei $n^{0}$ 5.537, de 21 de novembro de $1968^{7}$, vinculada ao Ministério da Educação - MEC, tem por missão institucional captar recursos financeiros e canalizá-los para o financiamento de programas e projetos voltados para a universalização da Educação Básica e à melhoria da qualidade do processo ensino-aprendizagem, de forma a reduzir as desigualdades sócio-educacionais entre os Municípios, Estados, Distrito Federal e regiões brasileiras, a exemplo dos Programas do Livro Didático, do Dinheiro Direto na Escola, da Alimentação Escolar e de Apoio ao Transporte do Escolar.

O FNDE também é o órgão responsável pela operacionalização do Fundo de Manutenção e Desenvolvimento da Educação Básica e de Valorização dos Profissionais da Educação - FUNDEB, criado pela Emenda Constitucional $n^{0}$ 53, de 19 de dezembro de 2006, regulamentado pela Lei $n^{\circ} 11.494$, de 20 de junho de 2007 e pelo Decreto $n^{\circ} 6.253$, de 13 de novembro de 2007, em substituição ao Fundo de Valorização do Ensino Fundamental - FUNDEF que vigorou entre 1998 a 2006.

\subsection{O Fundo de Manutenção e Desenvolvimento da Educação Básica e de Valorização dos Profissionais da Educação - FUNDEB}

\subsubsection{Histórico}

A discussão sobre vinculação de recursos da educação, a obrigatoriedade de parte dos impostos arrecadados serem aplicados na educação e mesmo a idéia da criação de “Fundos” para a educação não são recentes no Brasil. Esse debate e essa institucionalização de regras e leis vêm desde o período Colonial, passando pelo Império e chegando até os dias de hoje. Não é um debate conclusivo e, obviamente, não será.

Se retornarmos ao Período Imperial, poderíamos afirmar que a maior causa do “afunilamento” da oferta de escolas foi econômica e financeira. As escolas eram custeadas

\footnotetext{
${ }^{7}$ Publicada no Diário Oficial da União de 22 nov. 1968
} 
pelo imposto sobre o consumo de mercadorias, cobrado pelas Províncias e depois pelos Estados. Na avaliação que faz Monlevade (1997, p. 107) ${ }^{8}$, naquela época a arrecadação de impostos era insuficiente para construir e custear mais escolas públicas. Essa relação da arrecadação de impostos com o investimento na educação mantém-se há muito tempo.

Posteriormente, a partir de 1930, ocorreu uma aceleração no crescimento de matrículas, de tal modo que a relação entre arrecadação de impostos e matrículas se tornou desproporcional. Nesse período, a disputa decorrente do processo de urbanização brasileira criava várias prioridades de investimento para o Setor Público: estradas, saúde, saneamento e educação.

Com a criação do Ministério da Educação e Cultura ${ }^{9}$, construiu-se um Sistema Nacional de Educação Federativo. Foi um longo período de crescimento industrial, logo, de crescimento de arrecadação. Durante 40 anos, entre 1931 e 1971, segundo Monlevade (1997, p. 34-35) ${ }^{10}$, a União aumentou seus investimentos em educação superior, os governos estaduais ampliaram as vagas nas escolas primárias e nos ginásios, e os municípios, com recursos financeiros carimbados, começaram a assumir a educação infantil e a alfabetização de adultos onde faltava a presença estadual ou onde sobravam recursos de impostos.

Os debates sobre fundos para a educação já ocorriam desde o início da década de 1930. Na Constituição de 1934, foi definida como competência do Conselho Nacional de Educação, conforme a Lei, a elaboração de um plano nacional de educação, a ser aprovado pelo Poder Legislativo, que sugerisse “[...] ao Governo as medidas que [julgasse] necessárias para a melhor solução dos problemas educativos bem como a distribuição adequada dos fundos especiais” (DAVIES, 2004a, p.18) ${ }^{11}$.

\footnotetext{
${ }^{8}$ Monlevade apud Viana (2006)

${ }^{9}$ O Ministério da Educação foi criado no Brasil em 14 de novembro de 1930 com o nome de Ministério da Educação e Saúde Pública. Sua criação foi um dos primeiros atos do Governo Provisório de Getúlio Vargas, que havia tomado posse em 3 de novembro. O primeiro Ministro da Educação foi Francisco Campos. Sua nomeação foi um ato de compensação do Governo Federal a Minas, pela participação na Revolução de 1930, mas resultou também da pressão de setores conservadores da Igreja Católica, liderados por Alceu Amoroso Lima. Campos já acumulava uma experiência de reformador da educação em Minas Gerais, na década de 1920. A reforma que fez no ensino primário e normal desse Estado foi pioneira no País. Seguia os postulados da "Escola Nova", que havia chegado ao Brasil pelas mãos de Anísio Teixeira e Fernando de Azevedo.

${ }^{10}$ Monlevade apud Viana (2006)

${ }^{11}$ Davies apud Viana (2006)
} 
Nessa Constituição foi instituída uma percentagem de recursos para a educação: a União e os Municípios deveriam aplicar nunca menos de 10\%, e os Estados e o Distrito Federal, nunca menos de $20 \%$, da renda resultante dos impostos na manutenção e no desenvolvimento dos sistemas educativos.

É provável que os legisladores daquela época se tenham inspirado no Manifesto dos Pioneiros da Educação Nova (AZEVEDO et al., 1932) ${ }^{12}$, que abordava a reconstrução educacional no Brasil, falando de uma autonomia da função educacional e afirmando que esta só seria possível, entre outras coisas, a partir da instituição de um "fundo especial ou escolar". Tal fundo seria constituído de patrimônios, impostos e rendas próprias, e administrado e aplicado exclusivamente no desenvolvimento da educação pelos próprios órgãos responsáveis pelo ensino. Na verdade, a Constituição de 1934 foi além, ao definir:

$1^{\circ}$ - As sobras das dotações orçamentárias, acrescidas das doações, percentagens sobre o produto de vendas de terras públicas, taxas especiais e outros recursos financeiros, constituirão, na União, nos Estados e nos Municípios, esses fundos especiais, que serão aplicados exclusivamente em obras educativas, determinadas em lei.

$2^{\circ}$ - Parte dos mesmos fundos se aplicará em auxílios a alunos necessitados, mediante fornecimento gratuito de material escolar, bolsas de estudo, assistência alimentar, dentária e médica.

A Constituição de 1937 cancelou essa vinculação. O apoio à iniciativa privada na educação também aparecia na Constituição de 1934, em que constava: “Os estabelecimentos particulares de educação gratuita primária ou profissional, oficialmente considerados idôneos, serão isentos de qualquer tributo” (DAVIES, 2004a, p. 19) ${ }^{13}$.

A Constituição de 1946, de certa forma, também afirmava apoio à iniciativa privada, ao vedar à União, aos Estados, ao Distrito Federal e aos Municípios a cobrança de impostos sobre: “[...] o patrimônio, a renda ou serviços de Partidos Políticos e de instituições de educação ou de assistência social, observados os requisitos fixados em lei complementar” (DAVIES, 2004a, p. 23).

\footnotetext{
${ }^{12}$ Azevedo apud Viana (2006)

${ }^{13}$ Davies apud Viana (2006)
} 
A vinculação de impostos foi retomada pela Constituição de 1946. Nela, segundo Monlevade (1997, p. 36) ${ }^{14}$, não só se falava da criação de impostos federais vinculados, mas também de mais impostos municipais carimbados para a educação:

uma porcentagem do FPM e outra das receitas tributárias próprias. O percentual de impostos da União para aplicação na educação retornou ao patamar de 10\%; nos Municípios foi elevado a 20\%, para aplicação na manutenção e desenvolvimento do ensino; nos Estados e no Distrito Federal, retornou a obrigatoriedade de aplicação de 20\% desses impostos.

A Emenda Constitucional n. ${ }^{\circ}$ 1, de 17 de outubro de 1969, estabeleceu pela primeira vez a possibilidade de intervenção dos Estados nos Municípios, quando estes não estivessem aplicando “[...] no ensino primário, em cada ano, 20\%, pelo menos, da receita tributária municipal” (DAVIES, 2004a, p. 26). Embora a vinculação de impostos federais tivesse sido relaxada após o Golpe de 64, foi no Governo Militar que se estabeleceu a contribuição adicional do salário-educação, criado pela mesma E C como alternativa à manutenção do ensino primário para os empregados (e seus filhos) das empresas comerciais, industriais e agrícolas (DAVIES, 2004a, p. 30) ${ }^{15}$.

Outra vinculação de recursos ocorreu em 1983, com a E C n. ${ }^{\circ} 24$, de $1^{\circ}$ de dezembro de 1983. Nela, foram ampliados anualmente os percentuais de recursos da União para nunca menos de 13\%, e dos Estados, do Distrito Federal e dos Municípios, para, no mínimo, 25\% da receita resultante de impostos, na manutenção e desenvolvimento do ensino. Essa Emenda foi proposta pelo Senador João Calmon ${ }^{16}$ (DAVIES, 2004a, p. 29-30).

Com a E C n ${ }^{0}$ 14/96, 60\% desses recursos da educação passaram a ser subvinculados ao ensino fundamental (60\% de $25 \%=15 \%$ dos impostos e transferências), sendo que parte dessa sub-vinculação de 15\% passava pelo Fundef, cuja partilha dos recursos destinados aos entres federados tinha como base o número de alunos do ensino fundamental atendido em cada rede de ensino.

\footnotetext{
${ }^{14}$ Monlevade apud Viana (2006)

${ }^{15}$ Davies apud Viana (2006)

${ }^{16}$ João de Medeiros Calmon nasceu em 7 de setembro de 1916, na cidade de Colatina - ES. Faleceu em 11 de janeiro de 1998. Advogado e jornalista, teve os seguintes mandatos: como Deputado Federal - de 1963 a 1967 e de 1967 a 1971; como Senador - 1971 a 1978, de 1979 a 1987 e de 1987 a 1995.
} 
Criado em dezembro de 1996, no ano seguinte o FUNDEF foi implantado de forma experimental no Estado do Pará e funcionou em todo o país de $1^{\circ}$ de janeiro de 1998 até 31 de dezembro de 2006.

Com a E C n ${ }^{\circ}$ 53, de 19 de dezembro de 2006, a sub-vinculação das receitas dos impostos e transferências dos estados, Distrito Federal e municípios passou para 20\% e sua utilização foi ampliada para toda a educação básica por meio do Desenvolvimento da Educação Básica e de Valorização dos Profissionais da Educação - FUNDEB, instituído pela Emenda em comento, regulamentado pela Medida Provisória $n^{\circ}$ 339, de 28 de dezembro de 2006, posteriormente convertida na Lei $n^{\circ}$ 11.494, de 20 de junho de 2007. Sua implantação foi iniciada em $1^{\circ}$ de janeiro de 2007, de forma gradual, com previsão de ser concluída em 2009, quando estará funcionando com todo o universo de alunos da educação básica pública presencial e os percentuais de receitas que o compõem terão alcançado o patamar de 20\% de contribuição.

\subsubsection{Operacionalização}

O FUNDEB promove a distribuição dos recursos com base no número de alunos da educação básica informado no censo escolar do ano anterior, de modo que são computados os estudantes matriculados nos respectivos âmbitos de atuação prioritária dos entes federativos (art. 211 da Constituição Federal), ou seja, os municípios recebem os recursos do Fundeb com base no número de alunos da educação infantil e do ensino fundamental, e os estados, com base nos alunos do ensino fundamental e médio.

No caso do Distrito Federal, a regra adotada, tanto para a distribuição quanto para a aplicação dos recursos, é adaptada à especificidade prevista no parágrafo único, art. 10 da Lei de Diretrizes e Bases da Educação - LDB (Lei no 9.394/96), que estabelece que “Ao Distrito Federal aplicar-se-ão as competências referentes aos Estados e aos Municípios”, ou seja, ao Distrito Federal aplica-se, no que couber, tanto a regra destinada aos Estados quanto a destinada aos Municípios.

Assim como foi o FUNDEF, o FUNDEB é um fundo especial de natureza contábil de âmbito estadual (um fundo por estado e Distrito Federal, num total de vinte e sete fundos), formado por parcela financeira federal e por recursos provenientes dos impostos e 
transferências dos estados, Distrito Federal e municípios, vinculados à educação por força do disposto no art. 212 da Constituição Federal.

Conforme previsto no art. $2^{\circ}$ da Lei $n^{\circ} 11.494$ de 2007, o FUNDEB destina-se:

...à manutenção e ao desenvolvimento da educação básica pública e à valorização dos trabalhadores em educação, incluindo sua condigna remuneração, observado o disposto nesta Lei.

$\mathrm{O}$ art. $3^{\circ}$ da Lei $\mathrm{n}^{\circ} 11.494$ de 2007, enumera as seguintes fontes de recursos do FUNDEB:

I - imposto sobre transmissão causa mortis e doação de quaisquer bens ou direitos previsto no inciso I do caput do art. 155 da Constituição Federal;

II - imposto sobre operações relativas à circulação de mercadorias e sobre prestações de serviços de transportes interestadual e intermunicipal e de comunicação previsto no inciso II do caput do art. 155 combinado com o inciso IV do caput do art. 158 da Constituição Federal;

III - imposto sobre a propriedade de veículos automotores previsto no inciso III do caput do art. 155 combinado com o inciso III do caput do art. 158 da Constituição Federal;

IV - parcela do produto da arrecadação do imposto que a União eventualmente instituir no exercício da competência que lhe é atribuída pelo inciso I do caput do art. 154 da Constituição Federal prevista no inciso II do caput do art. 157 da Constituição Federal;

V - parcela do produto da arrecadação do imposto sobre a propriedade territorial rural, relativamente a imóveis situados nos Municípios, prevista no inciso II do caput do art. 158 da Constituição Federal;

VI - parcela do produto da arrecadação do imposto sobre renda e proventos de qualquer natureza e do imposto sobre produtos industrializados devida ao Fundo de Participação dos Estados e do Distrito Federal - FPE e prevista na alínea $a$ do inciso I do caput do art. 159 da Constituição Federal e no Sistema Tributário Nacional de que trata a Lei $\mathrm{n}^{0} 5.172$, de 25 de outubro de 1966;

VII - parcela do produto da arrecadação do imposto sobre renda e proventos de qualquer natureza e do imposto sobre produtos industrializados devida ao Fundo de Participação dos Municípios - FPM e prevista na alínea b do inciso I do caput do art. 159 da Constituição Federal e no Sistema Tributário Nacional de que trata a Lei $n^{0}$ 5.172, de 25 de outubro de 1966;

VIII - parcela do produto da arrecadação do imposto sobre produtos industrializados devida aos Estados e ao Distrito Federal e prevista no inciso II do caput do art. 159 da Constituição Federal e na Lei Complementar $n^{\circ}$ 61, de 26 de dezembro de 1989; e

IX - receitas da dívida ativa tributária relativa aos impostos previstos neste artigo, bem como juros e multas eventualmente incidentes.

$\S 1^{\circ}$ Inclui-se na base de cálculo dos recursos referidos nos incisos do caput deste artigo o montante de recursos financeiros transferidos pela União aos 
Estados, ao Distrito Federal e aos Municípios, conforme disposto na Lei Complementar $n^{\circ}$ 87, de 13 de setembro de 1996.

Nos estados em que não é atingindo o valor por aluno ${ }^{17}$, a União complementa com recursos financeiros tal valor.

Diferentemente do FUNDEF, onde a parcela de 15\% dos recursos arrecadados com o FPE, FPM, ICMS e IPIexp compunha o fundo, no FUNDEB, as parcelas aumentaram progressivamente: 16,66\% em 2007; 18,33\% em 2008 devendo atingir o patamar de 20\% em 2009, com previsão de manutenção deste índice para o período de 2010 a $2020^{18}$. Os percentuais de cada uma das fontes de recursos estão descritos no quadro a seguir:

TABELA 1

PERCENTUAIS DE RECURSOS DE CADA FONTE ALOCADOS NO FUNDEB

\begin{tabular}{|c|c|c|c|c|}
\hline RECEITA/ANO & 2007 & 2008 & 2009 & $2010 / 2020$ \\
\hline FPE & $16,66 \%$ & $18,33 \%$ & \multicolumn{2}{|r|}{$20 \%$} \\
\hline FPM & $16,66 \%$ & $18,33 \%$ & \multicolumn{2}{|r|}{$20 \%$} \\
\hline ICMS & $16,66 \%$ & $18,33 \%$ & \multicolumn{2}{|r|}{$20 \%$} \\
\hline IPIE/exp & $16,66 \%$ & $18,33 \%$ & \multicolumn{2}{|r|}{$20 \%$} \\
\hline Desoneração das Exportações & $16,66 \%$ & $18,33 \%$ & \multicolumn{2}{|r|}{$20 \%$} \\
\hline ITCMD (*) & $6,66 \%$ & $13,33 \%$ & \multicolumn{2}{|r|}{$20 \%$} \\
\hline IPVA $(*)$ & $6,66 \%$ & $13,33 \%$ & \multicolumn{2}{|r|}{$20 \%$} \\
\hline $\operatorname{ITR}(*)$ & $6,66 \%$ & $13,33 \%$ & \multicolumn{2}{|r|}{$20 \%$} \\
\hline Complementação da União $\left.{ }^{* *}\right)$ & R\$ 2 bilhões & R\$ 3 bilhões & $\begin{array}{c}\text { R\$ 4,5 } \\
\text { bilhões }\end{array}$ & $\begin{array}{c}10 \% \text { da } \\
\text { contribuição de } \\
\text { estados e } \\
\text { municípios }\end{array}$ \\
\hline
\end{tabular}

(*) o inciso I, § $1^{\circ}$ do art. 31 da Lei no 11.494 de 2007 define a progressão desses impostos conforme aqui demonstrado.

$\left(^{*}\right)$ Nos Estados em que não é atingido o valor por aluno, a União complementa com recursos financeiros tal valor. Também é importante frisar que o art. 31 da Lei n ${ }^{\circ} 11.494$ de 2007, em seu art. 31, inciso $4^{\circ}$, determina que "os valores a que se referem os incisos I, II e III do § 30 deste artigo serão atualizados, anualmente, nos primeiros 3 (três) anos de vigência dos Fundos, de forma a preservar em caráter permanente o valor real da complementação da União”.

\footnotetext{
${ }^{17}$ a fixação do valor mínimo por aluno esta contida no § $1^{\circ}$, art. $4^{\circ}$ da Lei ${ }^{\circ} 11.494$ de 20 jun.2007

${ }^{18}$ os índices estão definidos nos incisos I e II do § $1^{\circ}$, art. 31 da Lei ${ }^{\circ} 11.494$ de 2007
} 
Como se pode observar na tabela acima, a parcela de ICMS participa da composição financeira do fundo na mesma proporção dos demais impostos, porém dada a magnitude dos valores arrecadados, o ICMS tornou-se a principal fonte de recursos do fundo.

Corroboram essa assertiva dados de 2007 retirados do sítio do FNDE, onde consta a informação de que o Estado do Espírito Santo alocou no fundo o total de R\$ 1,060 bilhão ${ }^{19}$.

Desse valor, a parcela correspondente ao ICMS foi de R\$ 794,9 milhões, o que equivale a $69 \%$ dos recursos do alocados no fundo, como pode ser visualizado no gráfico 1.

\section{GRÁFICO 1}

\section{PERCETUAL DOS IMPOSTOS ALOCADOS NO FUNDEB PELO ESTADO DO ESPIRITO SANTO NO EXERCÍCIO DE 2007}

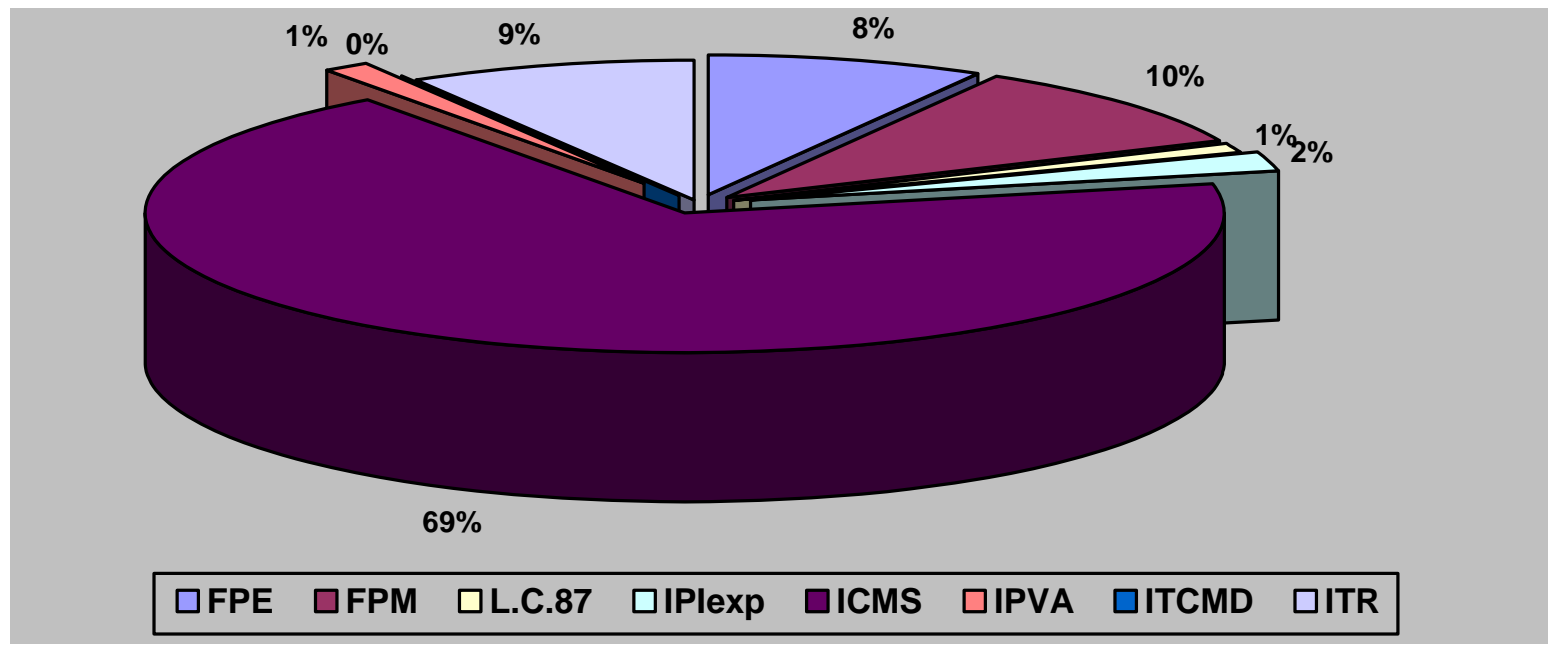

2.2.3 O valor mínimo nacional por aluno/ano

O valor mínimo nacional por aluno/ano representa o valor anual mínimo per capita. Aos entes governamentais localizados no estado cujo valor por aluno/ano (item 2.2.4) seja inferior a esse mínimo é assegurado o repasse de recursos advindos da complementação da União .

Para o calculo do valor mínimo nacional, ${ }^{20}$ são consideradas as seguintes variáveis do Fundo:

\footnotetext{
${ }^{19}$ disponível em http://www.fnde.gov.br/home/index.jsp?arquivo=fundeb.html\#consultas, acessado em 20/12/2008.

${ }^{20}$ a fixação do valor mínimo nacional esta contida no § $1^{\circ}$, art. $4^{\circ}$ da Lei no 11.494 de 2007
} 
. total geral da receita prevista para o FUNDEB no exercício (contribuição de Estados, Distrito Federal e Municípios);

. número de alunos matriculados, por segmentos da educação básica considerados;

. fatores de diferenciação do valor por aluno/ano;

. valor da complementação da União para o exercício (depois de deduzida parcela de até $10 \%$ direcionada à melhoria da qualidade da educação básica, caso seja estabelecida para o exercício).

Para 2008, o valor mínimo foi estabelecido em $\mathrm{R} \$ 1.132,34^{21}$ (para os anos iniciais do ensino fundamental urbano). A definição para os demais exercícios é publicada até 31 de dezembro de cada ano, para vigorar no ano seguinte.

\subsubsection{O valor por aluno}

Para cada Estado e o Distrito Federal é calculado um valor por aluno/ano, tomando como base apenas os recursos provenientes da contribuição do governo distrital e estadual e dos governos municipais do respectivo ente federado (sem os recursos da complementação da União), o número de alunos e os fatores de ponderação. Esse cálculo é realizado pelo emprego da seguinte fórmula:

\begin{tabular}{|c|c|}
\hline $\begin{array}{l}V A i=F i / N P i \\
\text { Sendo: } \\
N P i=\Sigma f j N j i \\
j=1\end{array}$ & $\begin{array}{l}\text { Onde: } \\
V A i=\text { Valor por aluno/ano das séries iniciais do ensino fundamental urbano, } \\
\text { no estado } i \text {; } \\
F i=\text { Total de recursos do Fundo no estado } i \text {, sem a complementação da } \\
\text { União; } \\
N P i=\text { Número de matrículas do estado } i \text {, ponderadas pelos fatores definidos } \\
\text { para esse fim; } \\
f j=\text { Fator de diferenciação aplicável ao segmento da educação básica } j \text {; } \\
N j i=\text { Número de alunos no segmento da educação básica } j \text { no estado } i \text {. }\end{array}$ \\
\hline
\end{tabular}

O per capita para cada segmento, entre os demais da educação básica, é calculado pela multiplicação desse valor para as séries iniciais do ensino fundamental urbano (VAi) pelo fator de diferenciação correspondente a cada segmento específico, na forma a seguir:

\footnotetext{
${ }^{21}$ valor estabelecido pelo Art. $2^{\circ}$ da Portaria Interministerial MEC/MF n ${ }^{\circ}$ 1.027, de 19 de agosto de 2007, publicada no Diário Oficial da União do dia 20/08/08, seção 1, pag. 19.
} 


\begin{tabular}{|l|l|}
\hline$V A j i=V A i f j$ & $\begin{array}{l}\text { Onde: } \\
V A j i=\text { Valor por aluno/ano para o segmento da educação básica } j \text { no } \\
\text { estado } i\end{array}$ \\
$V A i=$ Valor por aluno/ano das séries iniciais do ensino fundamental \\
urbano, no estado $i ;$ \\
$f j=$ Fator de diferenciação aplicável ao segmento da educação básica $j$.
\end{tabular}

Caso o valor por aluno/ano seja inferior ao mínimo nacional por aluno/ano vigente, torna-se necessária a garantia de recursos federais a título de complementação ao Fundo no âmbito do Estado. Essa complementação ocorre, portanto, com o objetivo de assegurar o valor mínimo estabelecido. Dessa forma, haverá complementação da União apenas naqueles Estados cujo per capita se situe abaixo do mínimo nacional. ${ }^{22}$

\subsection{O Fundo para Desenvolvimento das Atividades Portuárias - FUNDAP}

\subsubsection{Histórico}

O Fundo para Desenvolvimento das Atividades Portuárias - FUNDAP foi criado no Estado do Espírito Santo pela Lei $\mathrm{n}^{\circ}$ 2.508, de 22 de maio de 1970, alterada pela Lei $\mathrm{n}^{\circ}$ 2.592, de 22 de junho de 1971 e regulamentada pelo Decreto $\mathrm{n}^{\circ}$ 163, de 15 de julho de 1971, tendo sido submetido após esta data a várias outras alterações, editadas ora sob a forma de decretos, ora sob a forma de normas administrativas, tais como a Lei $n^{\circ} 2.696 / 72$, Lei $n^{\circ}$ 4.202/88, Lei no 4.972/94 e Decretos nº 557-E/72, 316/72, 449/78, 114/78, 2.018/80, 2085/58 e 2.449/87, além de Portarias, Decisões e outras tantas normas de cunho administrativo que alteram prazo de recolhimento do ICMS, garantias e aprovação de projetos.

\footnotetext{
${ }^{22}$ É importante frisar que, no caso dos valores por aluno/ano calculados no âmbito do ensino fundamental para as séries iniciais urbanas, as séries iniciais rurais, as quatro séries finais urbanas, as quatro séries finais rurais e a educação especial ficarem inferiores aos valores por aluno/ano verificados no último ano de vigência do FUNDEF (2006), devidamente corrigidos pelo INPC, permanecendo a defasagem, considera-se o valor do FUNDEF no seu ultimo ano de existência (2006).
} 
Tendo como gestor dos recursos o Banco de Desenvolvimento do Espírito Santo S/A - BANDES, o FUNDAP ainda passou por diversas modificações, sendo a última através da Lei $n^{0} 5.245$, de 03 de julho de $1996^{23}$.

\subsubsection{Origem dos recursos do FUNDAP}

Em conformidade com o disposto no art. $2^{\circ}$ da Lei ${ }^{\circ}$ 2.508, de 1970, o FUNDAP será constituído por recursos financeiros provenientes de dotações constantes na Lei de Orçamento Anual do Estado e créditos adicionais a ele destinados, transferências realizadas por entidades da Administração Indireta relacionadas com a atividade portuária e que tenham sua receita acrescida em virtude dos financiamentos de que trata esta Lei; amortização dos financiamentos concedidos, e de outras fontes definidas em Decreto do Poder Executivo.

Do ICMS total recolhido ao Estado (12\% ou $17 \%$ da operação, conforme o destino da importação), a empresa contribuinte tem direito a receber de volta $8 \%$ sob a forma de financiamento, ou seja, o Estado retira da arrecadação do ICMS 8\%, antes de calcular o montante a ser alocado no FUNDEB.

\subsubsection{Objetivo}

O objetivo do FUNDAP, conforme consta do art. $1^{\circ}$ da Lei $n^{\circ} 2.508$, de 1970, é “... promover o incremento das exportações e importações através do Porto de Vitoria”.

Os recursos arrecadados pelo FUNDAP são emprestados às empresas ditas Fundapianas a juros de 1\% (um por cento) ao ano, sem atualização monetária, com prazo de amortização de 20 (vinte) anos e carência de 05 (cinco) anos, totalizando 25 (vinte e cinco) anos.

Conforme definido no art. $6^{\circ}$ da Lei $\mathrm{n}^{\circ} 2508$ de 1970,

Os financiamentos de que trata esta Lei destinar-se-ão: a) no sentido da exportação, a mercadorias e equipamentos que, nos últimos 10 (dez) anos, não tenham excedido a 5\% (cinco por cento) do total em cruzeiros exportados em cada ano pelo Porto de Vitória; b) no sentido da importação, prioritariamente a matérias-primas destinadas a industrialização e a equipamentos industriais.

${ }^{23}$ publicada no Diário Oficial do Estado do Espírito Santo de 03/07/1996. 
Segundo Garcia ${ }^{24}$, com esses benefícios, pretendia-se ampliar a renda do setor terciário do Estado, através do incremento e diversificação do intercâmbio comercial com o exterior e ampliar a renda dos setores primário e secundário do Estado por meio da promoção de novos investimentos em projetos agropecuários, industriais, de pesca, de turismo, de florestamento e reflorestamento, de serviço, de saúde, de educação, social, de transporte, de infra-estrutura não governamental, de construção, de natureza cultural ou de comércio.

\subsubsection{Operacionalização}

A operacionalidade do FUNDAP, considerando o fluxo da importação, se materializa da seguinte maneira:

I - ocorre a importação;

II - os bens importados são internados no país e entram no estabelecimento importador, através do desembaraço aduaneiro realizado no território do Espírito Santo;

III - o ICMS tem postergado o seu recolhimento (Decreto 1.010-R de 05 de março de 2002) para o $26^{\circ}$ (vigésimo sexto) dia do mês seguinte ao do fato gerador;

IV - transcorrido este prazo, o ICMS é recolhido aos cofres estaduais, no seu valor integral e nominal, decorrente do valor de saída daqueles bens;

V - após o recolhimento do ICMS, o Banco de Desenvolvimento do Espírito Santo BANDES destina $8 \%$ do valor arrecadado para os empréstimos às empresas beneficiárias do FUNDAP.

2.3.4.1 Condições do financiamento:

a) Prazo

Os empréstimos são concedidos para pagamento em 20 anos com carência de 05 anos, totalizando 25 anos.

b)Encargos

No período de carência e de amortização, os juros são de $1 \%$ ao ano e não existe qualquer indexador ou correção monetária.

c) Condição Especial

\footnotetext{
${ }^{24}$ GARCIA, F. J. T. A Distribuição de ICMS aos Municípios do Espírito Santo: Concentração ou Desconcentração?. 2002. Dissertação (Mestrado em Gestão Empresarial) - EBAPE, Fundação Getulio Vargas, Rio de Janeiro.
} 
No momento da liberação do empréstimo, 7\% do seu valor ficam retidos no BANDES, em CDBs de titularidade do importador. Até o último dia do exercício seguinte ao da contratação do financiamento 7\% do seu valor devem ser aplicados em projeto próprio ou de terceiros, nos setores industrial, agrícola, ou desenvolvimento.

d) Garantias

Garantia pessoal dos sócios majoritários da empresa mutuaria ou de terceiros (não ligados às empresas), sejam pessoas físicas ou jurídicas. Alienação fiduciária das ações representativas dos investimentos vinculados.

e) Forma de amortização

Os empréstimos são quitados por meio de parcelas anuais.

Uma opção de quitação do financiamento é a utilização do Leilão administrativo ${ }^{25}$ onde os contratos de financiamento com recursos do FUNDAP poderão ser periodicamente objeto de oferta pública, visando a liquidação antecipada dos mesmos, observadas as seguintes condições: I - pagamento em moeda corrente equivalente a, no mínimo 15\% dos saldos devedores dos contratos de financiamento apurados na data da liquidação; II - que estejam realizados os investimentos decorrentes desses contratos exigidos na forma da Lei, ou que sejam depositados no BANDES os respectivos recursos para cumprimento dessa obrigação; III - os contratos poderão ser cedidos mediante leilão, observado o preço mínimo estabelecido.

\subsubsection{O impacto no FUNDEF}

Em decorrência dessa sistemática, durante o período em que vigorou o FUNDEF (1996 a 2006), os recursos alocados pelo Estado do Espírito Santo, sofreram uma crescente redução. Levantamento realizado por Viana ${ }^{26}$ demonstra a evolução ano a ano da redução dos recursos, oriundos do ICMS, alocados no FUNDEF no período de 1999 a 2004.

\footnotetext{
${ }^{25}$ Manual Operacional do FUNDAP/BANDES - Banco de Desenvolvimento do Espírito Santo S/A. Disponível em : HTTP://www.bandesonline.com.br/downloads/fundap04.doc , acessado em 20/12/2008.

${ }^{26}$ VIANA, A. S. R. O Fundef no Espírito Santo: processos instituídos nas políticas públicas para o ensino fundamental do município de Vitória. 2006. 220f, Dissertação (Mestrado em Educação, na linha de pesquisa: História, Sociedade, Cultura e Políticas Educacionais) - Centro de Educação, Universidade Federal do Espírito Santo, Vitória, pag. 122
} 
A tabela 2, retrata melhor tal situação. A quarta coluna destaca a diferença (D) entre os 15\% do total de ICMS arrecadado pelo Estado do Espírito Santo (B), que deveria ser repassado ao FUNDEF, deduzido o que efetivamente foi repassado ao FUNDEF (C).

TABELA 2

RECURSOS ORIUNDOS DO ICMS NÃO ALOCADOS NO FUNDEF

\begin{tabular}{|c|c|c|c|c|}
\hline Ano & $\begin{array}{l}\text { 100\% do ICMS } \\
\text { arrecadado } \\
\text { (A) }\end{array}$ & $\begin{array}{l}\text { Valor devido ao } \\
\text { FUNDEF } \\
\begin{array}{c}\text { (B) }=(15 \% \text { de } \\
\text { A) }\end{array}\end{array}$ & $\begin{array}{c}\text { ICMS } \\
\text { efetivamente } \\
\text { disponibilizado } \\
\text { (C) }\end{array}$ & $\begin{array}{l}\text { Diferença a ser } \\
\text { disponibilizada } \\
\text { (D) }=(B-C)\end{array}$ \\
\hline 1999 & $1.550 .383 .600,00$ & $232.557 .500,00$ & 184.248.200,00 & $48.309 .400,00$ \\
\hline 2000 & $1.997 .992 .400,00$ & 299.698.900,00 & 229.742.600,00 & 69.956.300,00 \\
\hline 2001 & 2.426.240.273,00 & $363.936 .041,00$ & 283.938.446,00 & 79.997.595,00 \\
\hline 2002 & 2.373.582.200,00 & 356.037.300,00 & 280.325.300,00 & 75.712.000,00 \\
\hline 2003 & 2.897.949.010,69 & 434.692.351,60 & 251.232.000,00 & $183.460 .351,60$ \\
\hline 2004 & $3.670 .194 .688,29$ & $550.529 .203,24$ & $298.624 .000,00$ & 251.905.203,24 \\
\hline \multicolumn{4}{|c|}{ TOTAL } & 709.340.849,84 \\
\hline
\end{tabular}

Evidentemente que parte desses recursos retornou ao FUNDEF e esta retornando ao FUNDEB, quando da amortização dos empréstimos concedidos por meio do FUNDAP ou por meio da realização de leilões.

A apuração dos valores retornados foge ao escopo do presente trabalho, porém é de fundamental importância que seja procedido criterioso e abalizado levantamento visando à apuração do quantum deverá retornar aos cofres do FUNDEB. 


\section{Conflitos de legislação}

3.1 Para o calculo do valor a ser alocado no FUNDEB, o Estado do Espírito Santo segue os ditames da Resolução, do Tribunal de Contas daquele Estado, no 195, de 20 de abril de $2004^{27}$, que em seu art. $2^{\circ}$ define que "O Fundo de Manutenção e Desenvolvimento do Ensino Fundamental e de Valorização do Magistério - FUDEF será composto por quinze por cento dos recursos definidos no art. $1^{\circ}$ da Lei n ${ }^{\circ}$ 9.424/96.”

Nos parágrafos $1^{\circ}$ e $2^{\circ}$ são definidos que:

$\S 1^{\circ}$ Computar-se-á como base de cálculo para a transferência de recursos ao FUNDEF, em âmbitos estadual e municipal, a receita dos juros, das multas moratórias e da correção monetária dos impostos de que trata o caput deste artigo, em respeito ao disposto na Lei Complementar no 63/90.

$\S 2^{\circ}$ Em âmbito estadual, as receitas originárias do imposto sobre operações relativas à circulação de mercadorias e sobre prestações de serviços de transporte interestadual e intermunicipal e de comunicação deverão ser ajustadas nos termos dispostos no artigo $1^{\circ}$, inc. I. alínea "g”, e do artigo $1^{\circ}$, § único, inc. II, desta resolução.

Os citados incisos e artigo determinam a base de cálculo para apuração dos valores mínimos a serem aplicados na manutenção e desenvolvimento do ensino bem como estabelece a subtração de receitas. Para maiores esclarecimentos, é o seguinte o contido no artigo $1^{\mathrm{o}}$ :

Art. $1^{\circ}$ A apuração dos valores mínimos a serem aplicados na manutenção e no desenvolvimento do ensino, conforme disposto no art. 212, da Constituição Federal, bem como no art. 60, do ADCT, dar-se-á da seguinte forma:

I -Para o Estado constituirá a base de cálculo o somatório:

g) das receitas resultantes das amortizações dos financiamentos concedidos no âmbito do Fundo para o Desenvolvimento das Atividades Portuárias (FUNDAP), inclusive o valor apurado em eventuais leilões

${ }^{27}$ publicada no Diário Oficial do Estado do Espírito Santo de 26/04/2004. 
correspondentes à liquidação antecipada dos saldos devedores dos contratos dos financiamentos respectivos.

Parágrafo único. Do somatório das receitas do Estado, conforme previsto no inciso I deste artigo deverão ser subtraídos os valores correspondentes:

$\mathrm{I}-\ldots$

II - aos financiamentos efetivamente concedidos no âmbito do Fundo para

o Desenvolvimento das Atividades Portuárias (FUNDAP), sendo assim considerados somente aqueles devidamente autorizados nos termos da legislação correspondente e liquidados de acordo com o art. 63, da Lei Federal n. ${ }^{\circ}$ 4.320, de 17 de março de 1964, até a data de encerramento de cada exercício, ou seja, 31 de dezembro de cada ano.

Como se verifica, o Estado do Espírito Santo retira parcela da arrecadação do ICMS destinado-a ao FUNDAP, modificando assim a base de cálculo para determinação dos valores a serem alocados no FUNDEB.

O retorno dos recursos ao FUNDEB fica postergado para um futuro não determinado, pois dependerá das amortizações de empréstimos ou do resultado dos leilões.

Como já demonstrado, o FUNDEB foi criado por dispositivo constitucional e devidamente regulamentado por Lei Federal. Assim nenhum de seus critérios poderá ser modificado por lei estadual, distrital ou municipal, pois tal ato contraria o disposto no art. 24, § $4^{\circ}$, da Constituição Federal, que assim estabelece:

$\S 4^{\circ}$ - A superveniência de lei federal sobre normas gerais suspende a eficácia da lei estadual, no que lhe for contrário.

3.2 Ao vincular recursos oriundos do ICMS, o Estado do Espírito Santo viola outro preceito constitucional, pois a vinculação de receitas de impostos a órgão ou fundo de despesa é vedada, ressalvados os casos apontados no inciso IV, art. 167 da Constituição Federal, que assim se pronuncia:

Art. 167. São vedados:

IV - a vinculação de receita de impostos a órgão, fundo ou despesa, ressalvadas a repartição do produto de arrecadação dos impostos a que se referem os arts. 158 e 159, a destinação de recursos para as ações e 
serviços públicos de saúde e para manutenção e desenvolvimento do ensino, como determinado, respectivamente, pelos art.s 198 , $\S 8^{\circ}$, bem como o disposto no $\S 4^{\circ}$ deste artigo;

A interpretação adotada pelo Tribunal de Contas do Estado do Espírito Santo, expressa na Resolução no 154/99, não guarda consonância com o espírito da Lei de criação do FUNDEB, pois a Resolução permite que parte do ICMS seja utilizada como incentivo fiscal na forma de empréstimo para o FUNDAP, deixando de contabilizar os recursos no FUNDEF.

É bem verdade que o inciso II, § único do art. $1^{\circ}$, prevê o retorno de valores à conta do FUNDEF (agora FUNDEB), porém não define quando os retornos serão efetuados e se serão atualizados monetariamente.

O assunto vem sendo discutido na esfera jurídica do MEC, desde a existência do FUNDEF. Foram emitidos vários documentos manifestando a posição contraria do MEC quando à sistemática adotada.

O MEC, por meio de sua Consultoria Jurídica, expediu em 14 de julho de 2004, a Informação $n^{\circ}$ 625/2004-CGAC, cujo item 7 expressava o entendimento no sentido de

... remeter o expediente à Secretaria de Coordenação Política e Assuntos Institucionais da Presidência da República que, por intermédio da Subchefia de Assuntos Federativos, poderá promover gestões junto ao Governo do Estado do Espírito Santo, visando equacionar o problema.

O tema foi analisado também pelo Ministério da Fazenda, sendo que a CoordenaçãoGeral de Programação Financeira, emitiu em 06 de fevereiro de 2002, a Nota Técnica $n^{\circ} 118$ de 2002, que em seu item 4 definia que

No que se refere a não inclusão dos acréscimos legais na base de cálculo do FUNDEF,o assunto tem sido tema em algumas reuniões do Conselho do FUNDEF. Entende-se que, por analogia com as Transferências Constitucionais de que trata o Art. 159 da CF, todos os gravames devem ser considerados no momento do cálculo dos repasses do ICMS ao FUNDEF. Ressalte-se que, pelo fato de alguns estados não estarem apropriando esses recursos na base de cálculo, a União tem transferido mais recursos do que os devidos, a título de Complementação. 
Mais adiante, no item 9 é proposto o encaminhamento do assunto à ProcuradoriaGeral da Fazenda Nacional, para “... manifestação sobre os aspectos supracitados de forma a amparar medidas de ajuste no âmbito do FUNDEF”. A Procuradoria analisou o assunto e emitiu o Parecer PGFN/CAF/N ${ }^{\circ}$ 1310/2003, tecendo varias considerações e culminando com a interpretação aposta no item 7, qual seja

Portanto, se o Estado do Espírito Santo tem destinado, por dispositivo constante de lei estadual, parcela da arrecadação do ICMS para determinado Fundo, no caso o FUNDAP, é flagrante a inconstitucionalidade dessa norma, por nítida violação ao que estabelece o inciso IV, do art. 167 da Constituição.

Apesar da flagrante inconstitucionalidade do ato praticado pelo Estado do Espírito Santo, o procedimento de retenção de parcela de recursos oriunda do ICMS, continuou a ser efetuado durante todo o período em que vigorou o FUNDEF e continua ocorrendo agora no FUNDEB. 


\section{Impacto financeiro no FUNDEB}

Analisando os dados constantes do balanço geral do exercício de 2007 do Estado do Espírito Santo ${ }^{28}$, extraímos que o Estado arrecadou R\$ 5.803.855.147,79 de Imposto de Circulação de Mercadorias e Serviço - ICMS. Assim sendo, e com base na Lei do FUNDEB $^{29}$, o Estado deveria alocar para este fundo o valor de R\$ 966.922.267,63, correspondente a $16,66 \%{ }^{30}$ do total arrecadado, porém destinou somente o valor de $\mathrm{R} \$$ 794.902.749,66, subtraindo R\$ 172.019.517,97 de receita ao FUNDEB.

A tabela 3 a seguir demonstra, de forma clara, o impacto negativo em Reais que o Estado do Espírito Santo acarretou ao FUNDEB no exercício de 2007.

\section{TABELA 3}

\section{IMPACTO NEGATIVO NO FUNDEB ${ }^{31}$}

\begin{tabular}{|c|c|c|c|}
\hline $\begin{array}{c}\text { ARRECADAÇÃO DO } \\
\text { ICMS/2007 }\left(^{*}\right)\end{array}$ & $\begin{array}{c}\text { VALOR QUE DEVERIA } \\
\text { ALOCAR AO FUNDEB } \\
(16,66 \% \text { do total } \\
\text { arrecadado })\end{array}$ & $\begin{array}{c}\text { VALOR } \\
\text { EFETIVAMENTE } \\
\text { ALOCADO AO } \\
\text { FUNDEB }(* *)\end{array}$ & DIFERENÇA \\
\hline $5.803 .855 .147,79$ & $966.922 .267,63$ & $794.902 .749,66$ & $172.019 .517,97$ \\
\hline
\end{tabular}

(*) Fonte: balanço geral do exercício de 2007 do Estado do Espírito Santo, disponível no site www.sefaz.es.gov.br, acessado em $10 / 12 / 2008$.

(**) Fonte: site do Fundo Nacional de Desenvolvimento da Educação, www.fnde.gov.br, acessado em 10/12/2008.

Os recursos do FUNDEB devem ser aplicados na manutenção e desenvolvimento da educação básica pública ${ }^{32}$, observando-se os respectivos âmbitos de atuação prioritária dos Estados e Municípios, conforme estabelecido nos $\S \S 2^{\circ}$ e $3^{\circ}$ do art. 211 da Constituição (os Municípios devem utilizar recursos do FUNDEB na educação infantil e no ensino fundamental e os Estados no ensino fundamental e médio), sendo que o mínimo de 60\% desses recursos deve ser destinado anualmente à remuneração dos profissionais do

\footnotetext{
${ }^{28}$ disponível no site www.sefaz.es.gov.br , acessado em 10/12/2008.

${ }^{29}$ Lei ${ }^{\circ} 11.494$ de 20 de junho de 2007.

${ }^{30}$ previsto no item I, § $1^{\circ}$ do art. 31 da Lei $n^{\circ} 11.494$ de 20 de junho de 2007.

${ }^{31}$ Cabe acrescentar que os valores aqui expressos, são meramente um exercício matemático, servem apenas para efeito de demonstração dos maléficos efeitos da retenção de recursos a serem alocados no FUNDEB, não servindo de base para nenhuma cobrança de valores devidos, pois tal cobrança é realizada seguindo ditames próprios emanados dos órgãos de controle do Governo Federal. A cobrança de valores não é o objetivo do presente trabalho.

32 determinação contida no art. 21 da Lei no 11.494 de 20/06/2007.
} 
magistério (professores e profissionais que exercem atividades de suporte pedagógico, tais como: direção ou administração escolar, planejamento, inspeção, supervisão e orientação educacional) em efetivo exercício na educação básica pública (regular, especial, indígena, supletivo), e a parcela restante (de no máximo 40\%), seja aplicada nas demais ações de manutenção e desenvolvimento, também da educação básica pública.

É oportuno destacar que, se a parcela de recursos para remuneração dos profissionais do magistério é de no mínimo 60\% do valor anual, não há impedimento para que se utilize até $100 \%$ dos recursos do FUNDEB na remuneração desses profissionais.

As ações de manutenção e desenvolvimento do ensino, são voltadas à consecução dos objetivos das instituições educacionais de todos os níveis. Inserem-se no rol destas ações, despesas relacionadas à aquisição, manutenção e funcionamento das instalações e equipamentos necessários ao ensino, uso e manutenção de bens e serviços, remuneração e aperfeiçoamento dos profissionais da educação, aquisição de material didático, transporte escolar, entre outros. Ao estabelecer quais despesas podem ser consideradas como de manutenção e desenvolvimento do ensino, a Lei 9.394/96 ${ }^{33}$ - LDB pressupõe que o sistema coloque o foco da educação na escola e no aluno.

O art. 70 da LDB enumera as ações consideradas como de manutenção e desenvolvimento do ensino, abaixo apresentamos algumas dessas ações:

a) Remuneração e aperfeiçoamento do pessoal docente e dos profissionais da educação:

_ habilitação de professores leigos;

_ capacitação dos profissionais da educação (magistério e outros servidores em exercício na educação básica), por meio de programas de formação continuada;

_ remuneração dos profissionais da educação básica que desenvolvem atividades de natureza técnico-administrativa (com ou sem cargo de direção ou chefia) ou de apoio, como, por exemplo, o auxiliar de serviços gerais, o auxiliar de administração, o(a) secretário(a) da escola, etc., lotados e em exercício nas escolas ou órgão/unidade administrativa da educação básica pública;

b) Aquisição, manutenção, construção e conservação de instalações e equipamentos necessários ao ensino:

_ aquisição de imóveis já construídos ou de terrenos para construção de prédios, destinados a escolas ou órgãos do sistema de ensino;

${ }^{33}$ publicada no Diário Oficial da União de 23/12/1996. 
_ ampliação, conclusão e construção de prédios, poços, muros e quadras de esportes nas escolas e outras instalações físicas de uso exclusivo do sistema de ensino;

- aquisição de mobiliário e equipamentos voltados para o atendimento exclusivo das necessidades do sistema da educação básica pública (carteiras e cadeiras, mesas, armários,mimeógrafos, retroprojetores, computadores, televisores, antenas, etc.);

_ manutenção dos equipamentos existentes (máquinas, móveis, equipamentos eletroeletrônicos, etc.), seja mediante aquisição de produtos/serviços necessários ao funcionamento desses equipamentos (tintas, graxas, óleos, energia elétrica, etc.), seja mediante a realização de consertos diversos (reparos, recuperações, reformas, reposição de peças, revisões, etc.);

_ reforma, total ou parcial, de instalações físicas (rede elétrica, hidráulica, estrutura interna, pintura, cobertura, pisos, muros, grades, etc.) do sistema da educação básica.

c) Uso e manutenção de bens vinculados ao sistema de ensino:

_ aluguel de imóveis e de equipamentos;

_ manutenção de bens e equipamentos (incluindo a realização de consertos ou reparos);

_ conservação das instalações físicas do sistema de ensino prioritário dos respectivos entes federados;

_ despesas com serviços de energia elétrica, água e esgoto, serviços de comunicação, etc.

d) Levantamentos estatísticos, estudos e pesquisas visando precipuamente ao aprimoramento da qualidade e à expansão do ensino:

- levantamentos estatísticos (relacionados ao sistema de ensino), objetivando o aprimoramento da qualidade e à expansão do atendimento no ensino prioritário dos respectivos entes federados;

_ organização de banco de dados, realização de estudos e pesquisas que visam à elaboração de programas, planos e projetos voltados ao ensino prioritário dos respectivos entes federados.

e) Realização de atividades-meio necessárias ao funcionamento do ensino:

_ despesas inerentes ao custeio das diversas atividades relacionadas ao adequado funcionamento da educação básica, dentre as quais pode se destacar: serviços diversos (de vigilância, de limpeza e conservação, dentre outros), aquisição do material de consumo utilizado nas escolas e demais órgãos do sistema de ensino (papel, lápis, canetas, grampos, colas, fitas adesivas, gizes, cartolinas, água, produtos de higiene e limpeza, tintas, etc.).

f) Aquisição de material didático-escolar e manutenção de transporte escolar:

_ aquisição de materiais didático-escolares diversos, destinados a apoiar o trabalho pedagógico na escola (material desportivo utilizado nas aulas de educação física, acervo da biblioteca da escola - livros, atlas, dicionários, periódicos, etc.; lápis, borrachas, canetas, cadernos, cartolinas, colas, etc.); 
_ aquisição de veículos escolares apropriados ao transporte de alunos da educação básica na zona rural, devidamente equipados e identificados como de uso específico nesse tipo de transporte, em observância ao disposto no Código Nacional de Trânsito (Lei nº 9.503, de 23.09.97).

g) Amortização e custeio de operações de crédito destinadas a atender ao disposto nos itens acima:

- quitação de empréstimos (principal e encargos) destinados a investimentos em educação (financiamento para construção de escola, por exemplo).

Assim, tomando-se o valor apurado como diferença, RS 172.019.517,97, e aplicando-se a regra de utilização dos recursos do FUNDEB, teríamos seguinte distribuição:

TABELA 4

DISTRIBUIÇÃO POR DESTINAÇÃO DA DIFERENÇA APURADA

\begin{tabular}{|c|c|c|}
\hline & REMUNERAÇÃO DOS & OUTRAS AÇÕES DE \\
& PROFISSIONAIS DO & MANUTENÇÃO E \\
DIFERENÇA & MAGISTÉRIO & DESENVOLVIMENTO DO \\
& $(60 \%)$ & ENSINO \\
& $\mathrm{R} \$ 10 \%)$ \\
\hline $\mathrm{R} \$ 172.019 .517,97$ & $\mathrm{R} \$ 68.807 .807,19$ \\
\hline
\end{tabular}

Admitindo-se que a parcela de 60\%, no valor de $\mathrm{R} \$ 103.211 .710,79$, destinada à remuneração dos profissionais do magistério ${ }^{34}$, fosse integralmente utilizada no pagamento dos docentes, fizemos duas projeções.

Em ambas projeções, utilizamos o Edital $n^{0} 1 / 2007^{35}$, no qual o Governo do Estado do Espírito Santo tornou público a realização de concurso público para provimento de vagas no cargo de Professor para o Ensino Médio.

No item 2.1 do Edital, entre outros, consta a informação de que a remuneração inicial seria definida em função da escolaridade do candidato. Assim o candidato que tivesse formação superior, acrescida de doutorado em educação com defesa e aprovação de tese, faria jus ao vencimento inicial de $\mathrm{R} \$ 1.085,39$.

\footnotetext{
34 a descrição dos “profissionais do magistério” esta contida no inciso II, § único do art. 22 da Lei n 11.494, de $20 / 06 / 2007$.

35 fonte: edital no 1/2007, publicado no Diário Oficial do Estado do Espírito Santo do dia 23/11/07, pag. 13, disponível em: www.dioes.com.br/pdfclipper/Pages/wfFolhear.aspx?d=does_20071123\&t=156\&p=13, acessado em 05/01/2009.
} 
Tendo como parâmetro tal vencimento, procedemos aos cálculos constantes da tabela 5, e verificamos que seria possível a contratação de 7.314 professores.

TABELA 5

CONTRATAÇÃO DE DOCENTES

\begin{tabular}{|c|c|c|c|}
\hline COLUNA “A” & COLUNA “B” & COLUNA “C” & COLUNA “D” \\
\hline $\begin{array}{c}\text { DIFERENÇA } \\
(\mathrm{R} \$)\end{array}$ & $\begin{array}{c}\text { SALARIO DO } \\
\text { PROFESSOR } \\
(\mathrm{R} \$)\end{array}$ & $\begin{array}{c}\text { TOTAL RECEBIDO EM 01 } \\
\text { ANO ((12 MESES + 13 } \\
\text { SALARIO) } \text { x coluna B) } \\
(\mathrm{R} \$)\end{array}$ & $\begin{array}{c}\text { TOTAL DE } \\
\text { PROFESSORES A } \\
\text { SEREM } \\
\text { CONTRATADOS } \\
(\mathrm{A} \div \mathrm{C})\end{array}$ \\
\hline $103.211 .710,79$ & $1.085,39$ & $14.110,07$ & 7.314 \\
\hline
\end{tabular}

Na segunda projeção, procedemos ao rateio da diferença apurada, utilizando-se o salário de R\$ 1.085,39 (item 2.1 do Edital 1/2007), e apuramos que seria possível o pagamento de um salário extra para 95.092 docentes, conforme cálculo constate da tabela 6, a seguir.

TABELA 6

PAGAMENTO DE SALÁLRIO EXTRA

\begin{tabular}{|c|c|c|}
\hline COLUNA “A” & COLUNA “B” & COLUNA “C” \\
\hline $\begin{array}{c}\text { DIFERENÇA } \\
(\mathrm{R} \$)\end{array}$ & $\begin{array}{c}\text { SALARIO DO PROFESSOR } \\
(\mathrm{R} \$)\end{array}$ & $\begin{array}{c}\text { TOTAL DE PROFESSORES } \\
\text { BENEFICIADOS } \\
(\mathrm{A} \div \mathrm{B})\end{array}$ \\
\hline $103.211 .710,79$ & $1.085,39$ & 95.092 \\
\hline
\end{tabular}

Considerando-se que a parcela de 40\%, no valor de $\mathrm{R} \$ 68.807 .807,19$ fosse integralmente utilizada na construção de salas de aula com metragem padrão de $48 \mathrm{~m}^{2}{ }^{36}$, e utilizando-se o valor do custo por $\mathrm{m}^{2}$ da construção civil no Estado do Espírito Santo para o

\footnotetext{
${ }^{36}$ Metragem constante do Manual do FUNDESCOLA- Padrões Mínimos de Funcionamento da Escola de Ensino Fundamental, disponível em ftp://ftp.fnde.gov.br/web/fundescola/publicacoes_manuais_tecnicos/pmfe_guia_consulta.pdf, acessado em 20/12/2008.
} 
mês de dezembro/2007 (R 533,88) ${ }^{37}$, no exercício de 2007 seria possível a construção de 2.686 salas de aula, pois:

$\mathrm{R} \$ 68.807 .807,19 \div\left(48 \mathrm{~m}^{2} \times \mathrm{R} \$ 533,88\right)=2.686$ salas de aula.

De outro lado, a alocação da diferença apurada no FUNDEB, transferida para anos após o fato gerador do ICMS, impõe um longo e inaceitável adiamento do investimento em favor da educação básica, bem como prenuncia uma redução de recursos face ao efeito corrosivo a que esses recursos são submetidos em decorrência da taxa de juros praticada (1\% ao ano), cujo percentual esta muito aquém das taxas praticadas no mercado financeiro.

A tabela 1, anexa, demonstra o qual danosa para a educação básica é o beneficio concedido ao setor exportador. Tomando-se o valor de R \$172.019.517, (diferença apurada), e considerando: a) o retorno do empréstimo nas regras do FUNDAP (taxa de juros de 1\% ao ano, 05 anos de carência e 20 para pagamento); b) o retorno do mesmo valor no mesmo período porem remunerado a taxa de $7,63 \%{ }^{38}$, obtemos o seguinte resultado:

o retorno do empréstimo de R 172.019 milhões nas regras do FUNDAP, totaliza R\$ 196.594 milhões.

o retorno do mesmo valor, aplicando-se a taxa de remuneração da poupança, totalizaria R \$ 482.066 milhões.

A diferença entre as duas formas de calculo é de R\$ 285.472 milhões, ou seja, um diferencial de 145\%. Esse diferencial apurado, representa o que deixa de ser canalizado para o FUNDEB em função de seu direcionamento para o FUNDAP.

O retorno desses valores ao FUNDEB está postergado para um futuro distante e incerto. A mensuração do montante de recursos retornados encontra sérios obstáculos, pois demandaria uma análise profunda dos balanços orçamentários/financeiros do Estado do Espírito Santo, em busca de tais informações, uma vez que nos balanços não se encontram de forma clara e objetiva os valores retornados (via amortização ou leilão) tampouco menção à informação do ano em que foram concedidos os empréstimos.

\footnotetext{
${ }^{37}$ apurado pelo Sistema Nacional de Pesquisa de Custos e Índice da Construção Civil - SINAPI, extraído do site www.cef.gov.br, acessado em 30/12/2008.

38 taxa acumulada de remuneração da poupança no ano de 2007, apurada pelo Banco Central do Brasil, disponível no site www.bcb.gov.br/pec/indeco/Port/ie3-09.xls, acessado em 30/12/2008.
} 
O impacto sócio-econômico, a partir da melhoria do ensino básico no Estado do Espírito Santo, é de difícil mensuração, e ultrapassa o cunho do trabalho ora apresentado e somente será apurado em sua plenitude com o acompanhamento sistemático das ações desenvolvidas, o desempenho e progressão curricular dos alunos e a evolução salarial dos professores. 


\section{Conclusão}

O procedimento de retirar parcela de recursos do ICMS antes de calcular o valor a ser alocado ao FUNDE, e direcioná-los para o FUNDAP, adotado pelo Estado do Espírito Santo, trouxe sérios prejuízos ao alcance dos objetivos do FUNDEF (quando de sua existência) e esta trazendo ao FUNDEB.

É flagrante o desrespeito a preceito constitucional, pois os procedimentos adotados pelo Estado, estão baseados em lei estadual e resoluções de seu tribunal de contas. O agravante é que já foram emitidos vários posicionamentos de órgãos federais condenando o procedimento estadual, mas por motivos obscuros a retenção de recursos não foi interrompida.

Com a reforma tributária em discussão no Congresso Nacional, é sabido que tanto o FUNDAP quanto os demais fundos instituídos com a finalidade de conceder incentivos fiscais a estados ou municípios, serão extintos e/ou impedidos de serem implantados. Assim a anomalia será sanada, porém restará um imenso hiato financeiro a ser recomposto no FUNDEB.

Claro está que por mais que sejam restituídos os recursos desviados do FUNDEB, jamais o "estrago” será recomposto, pois não é possível repor o salário não pago no mês de sua competência e a sala de aula não construída no momento exato de sua necessidade.

Acrescente-se o fato de que, seguindo as regras do FUNDAP, a alocação de recursos ao FUNDEB, transferida para anos após o fato gerador do ICMS, impõe um longo e inaceitável adiamento do investimento em favor da educação básica, bem como prenuncia uma redução de recursos face ao efeito corrosivo a que os recursos são submetidos em decorrência da taxa de juros praticada (1\% ao ano), muito aquém das taxas praticadas no mercado financeiro.

O verdadeiro impacto da redução de recursos alocados no FUNDEB, somente será apurado em sua plenitude com o acompanhamento sistemático das ações desenvolvidas, o desempenho e progressão curricular dos alunos e a evolução salarial dos professores.

Uma das dificuldades para realização do presente trabalho, foi determinar os valores restituídos ao FUNDEF e ao FUNDEB decorrentes da amortização dos empréstimos 
concedidos às empresas beneficiárias do sistema FUNDAP, pois o balanço geral do Estado não demonstra de forma clara e objetiva a que empréstimo aquele valor retornado se refere ou em que exercício foi concedido o empréstimo cuja parcela agora retorna aos cofres estaduais.

Dessa forma, fica a sugestão de que seja designada equipe técnica, composta por membros do Ministério da Educação, Ministério da Fazenda e mesmo Tribunal de Contas da União, com a finalidade única de proceder criterioso levantamento nas contas do Estado do Espírito Santo, visando determinar com exatidão o montante de recursos não alocados no FUNDEF e no FUNDEB.

O resultado final do levantamento deverá expressar de forma clara e objetiva o total não alocado, descriminando-o por exercício financeiro onde fique evidenciado o valor não alocado e os retornos de recursos (devidamente identificados com a indicação do ano em que ocorreu o fato gerador e o valor desviado). 


\section{Referências}

BRASIL. Constituição (1998). Brasília: Senado Federal, 2003.

Lei $\mathbf{n}^{\circ}$ 4.320, de 17de março de 1964. Lei de Orçamento e Contabilidade Pública.

Fiscal.

Lei Complementar $n^{0}$ 101, de 04 de maio de 2000. Lei de Responsabilidade

Lei n 9.424, de 24de dezembro de 1996. Lei de criação do FUNDEF.

Lei n 9.394, de 20 de dezembro de 1996. Lei de Diretrizes e Bases da Educação.

Lei no 11.494, de 20 de junho de 2007. Lei de regulamentação do FUNDEB.

Lei no 5.537, de 21 de novembro de 1968. Lei de criação do FNDE.

Portaria Interministerial MEC/MF $n^{0}$ 1.027, de 19 de agosto de 2007. Estabelece o cálculo dos parâmetros operacionais do FUNDEB para 2008. FUNDEB.

Emenda Constitucional $n^{\circ}$ 53, de 19 de dezembro de 2000. Instituiu o FUNDEB.

Medida Provisória $n^{0}$ 339, de 28 de dezembro de 2000. Regulamenta 0

Emenda Constitucional $n^{0} 1$, de 17 de outubro de 1969. Estabelece a complementação financeira da União.

Emenda Constitucional $n^{0}$ 24, de 01 de dezembro de 1983. Amplia os percentuais de participação financeira da União.

Nota Técnica $\mathrm{n}^{0}$ 118, de 06 fev. 2002. Pronunciamento quanto ao tratamento utilizado pelo Estado do Espírito Santo na apuração da base de cálculo do ICMS para efeito de incidência de percentual destinado ao FUNDEF. Ministério da Fazenda - Coordenação Geral de Programação Financeira. 
Parecer PGFN/CAF/No 1310/2003, de 12 ago. 2003. Questionamentos oriundos do Conselho Social do FUNDEF. Ministério da Fazenda - Procuradoria-Geral da Fazenda Nacional.

Informação $n^{0}$ 625/2004-CGAC, de 14 jul. 2004. O Fundo para o Desenvolvimento das Atividades Portuárias - FUNDAP instituído pelo Estado do Espírito Santo utiliza os recursos do ICMS, reduzindo a base de cálculo do FUNDEF e afrontando o Texto Constitucional. Ministério da Educação - Consultoria Jurídica.

ESPIRITO SANTO. Balanço Geral do exercício de 2007. Disponível em http://www.sefaz.es.gov.br/ . Acessado em $10 \mathrm{dez} 2008$.

. Lei $\mathbf{n}^{0}$ 2.508, de 22 de maio de 1970. Lei de criação do FUNDAP.

Diário Oficial do dia 23/11/07, pag. 13, disponível em: www.dioes.com.br/pdfclipper/Pages/wfFolhear.aspx?=does_20071123\&t=156\&=13, acessado em 05 jan. 2009.

$\underset{\text { Santo }}{\text { Manual Operacional do FUNDAP/BANDES - Banco de Desenvolvimento do }}$
$\begin{aligned} & \text { Espírito } \\ & \text { HTTP://www.bandesonline.com.br/downloads/fundap04.doc , acessado em } 20 \mathrm{dez} .2008 .\end{aligned}$

GIL, Antônio Carlos. Como elaborar projetos de pesquisa. $3^{\text {a }}$ Ed. São Paulo: Atlas, 1996.

Claudiano, A.; MEDEIROS, M.; FEIJÓ, P. H. Gestão de Finanças Públicas: Fundamentos e Práticas de Planejamento, Orçamento e Administração Financeira com Responsabilidade Fiscal. 1 ${ }^{\mathrm{a}}$ ed. Cidade Gráfica e Editora: 2006.

FUNDO NACIONAL DE DESENVOLVIMENTO DA EDUCAÇÃO. Manual de Orientação do FUNDEB/2008. disponível em www.fnde.gov.br, acessado em 10 dez. 2008.

VIANA, A. S. R. O Fundef no Espírito Santo: processos instituídos nas políticas públicas para o ensino fundamental do município de Vitória. 2006. 220f, Dissertação (Mestrado em Educação, na linha de pesquisa: História, Sociedade, Cultura e Políticas Educacionais) - Centro de Educação, Universidade Federal do Espírito Santo, Vitória. 
CAIXA ECONÔMICA FEDERAL. Sistema Nacional de Pesquisa de Custos e Índice da Construção Civil - SINAPI, disponível em www.cef.gov.br, acessado em 30 dez. 2008.

BANCO CENTRAL DO BRASIL. taxa acumulada de remuneração da poupança no ano de 2007, disponível em www.bcb.gov.br/pec/indeco/Port/ie3-09.xls, acessado em 30 dez. 2008.

GARCIA, F. J. T. A Distribuição de ICMS aos Municípios do Espírito Santo: Concentração ou Desconcentração?. 2002. 221f, Dissertação (Mestrado em Gestão Empresarial) - EBAPE, Fundação Getulio Vargas, Rio de Janeiro. 
ANEXO A - Retorno do financiamento 
RETORNO DE FINANCLAMENTO CONSIDERANDO ENCARGOS DE 1\% AO ANO X RESULTADO DE APLICAC̣ÃO EM POUPANÇA REMUNERADA APENAS COM JUROS DE $7,63 \%$ AO ANO.

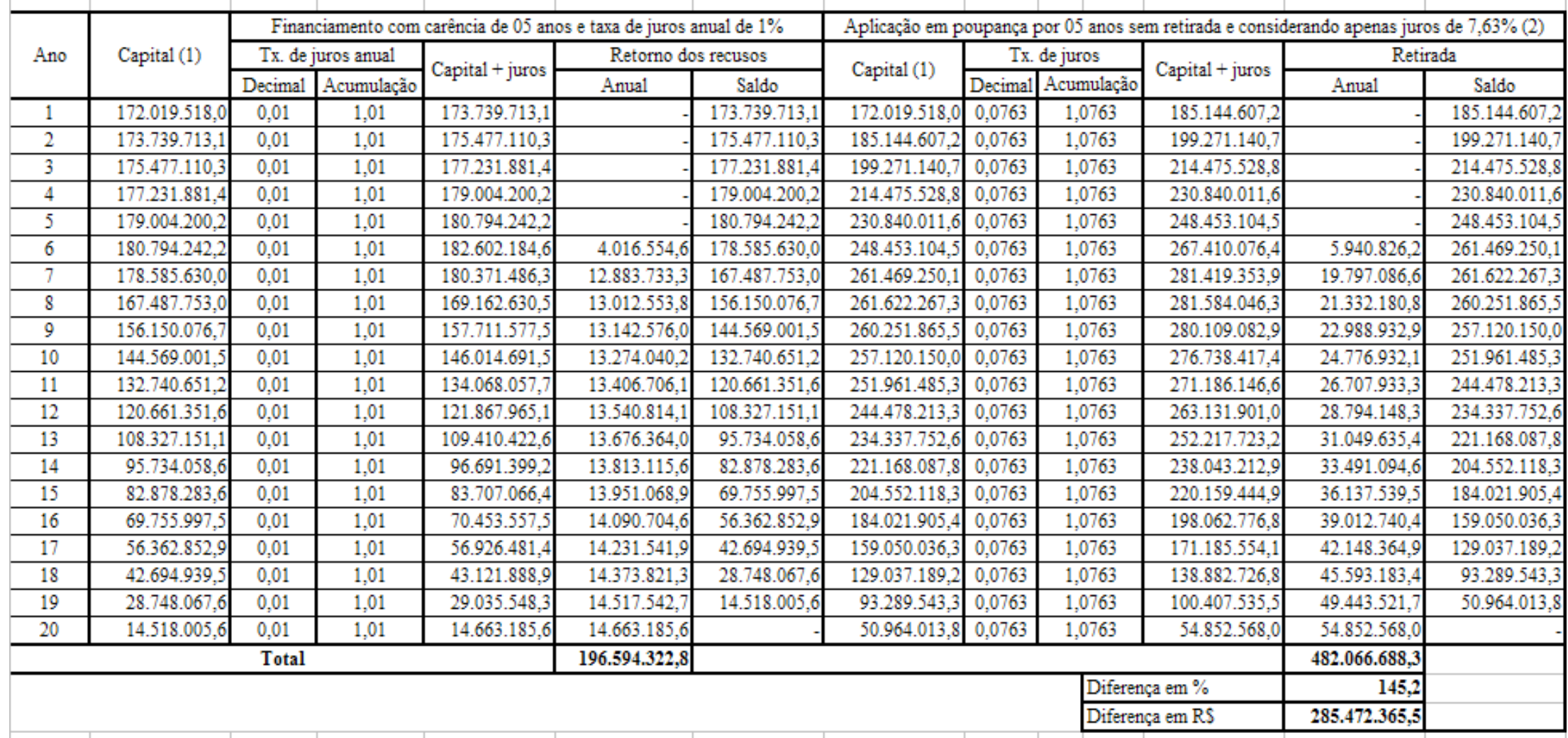

(1) diferença apurada entre o que deveria ser alocado de ICMS ao FUNDEB é o que de fato foi alocado.

(2) taxa acumulada de remuneração da poupança no exercício de 2007 (extraído do site: www.bcb.gov.br/pec/indeco/Port/ie3-09.xls, acessado em 30/12/08) não foi considerado o efeito inflacionário sobre o calculo do rendimento da poupança. O resultado espelha somente a aplicação da taxa de juro. 